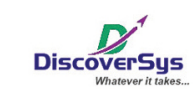

Published by DiscoverSys

\section{Prevalensi dan faktor penentu prediabetes pada wanita muda obesitas di Kota Denpasar tahun 2019}

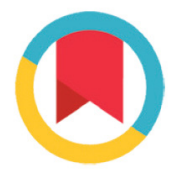

CrossMark

\author{
Dinda Anggita Meiwita Sari ${ }^{1 *}$, Desak Ketut Ernawati ${ }^{2}$, Agung Nova Mahendra² ${ }^{2}$ I Wayan Weta ${ }^{3}$
}

\title{
ABSTRACT
}

Background: The prevalence of prediabetic state in population is such a hard project to be confirmed within an increased number of obese population.

Aim: The study aims to define the prevalence of prediabetes among obese young women (body mass index, BMI $>25 \mathrm{~kg} / \mathrm{m}^{2}$ ) in Denpasar.

Methods: Research variables namely physical activity, food pattern, anthropometric values for identify level of obesity (light BMI 2530 , severe BMI $>30 \mathrm{~kg} / \mathrm{m}^{2}$ ), tipe of obesity (perifer obesity waist circumference $<80 \mathrm{~cm}$, and central obesity waist circumference $\geq 80 \mathrm{~cm}$ ), as well as fasting blood glucose (normal $<100 \mathrm{mg} / \mathrm{dL}$, prediabetes $-125 \mathrm{mg} / \mathrm{dL}$ ).

Keywords: Prediabetes, Insulin resistance, Diabetes Mellitus, risk factors, Obesity, central obesity

Cite This Article: Sari, D.A.M.S., Ernawati, S.K., Mahendra, A.N., Weta, I.W. 2020. Prevalensi dan faktor penentu prediabetes pada wanita muda obesitas di Kota Denpasar tahun 2019. Intisari Sains Medis 11 (3): 1000-1004. D0I: 10.15562/ism.v11i3.701

\section{ABSTRAK}

'Program Studi Sarjana Kedokteran dan Profesi Dokter, Fakultas Kedokteran, Universitas Udayana 2Departemen Farmakologi, Fakultas Kedokteran, Universitas Udayana

${ }^{3}$ Departemen Kesehatan Masyarakat dan Kedokteran Pencegahan, Fakultas Kedokteran Universitas Udayana

\section{*Korespondensi:} Dinda Anggita Meiwita Sari; Program Studi Sarjana Kedokteran dan Profesi Dokter, Fakultas Kedokteran, Universitas Udayana; danggitams@gmail.com

Diterima: 26-01-2020 Disetujui: 28-09-2020 Diterbitkan: 15-10-2020
Latar Belakang: Peningkatan prevalensi obesitas bersamaan dengan prevalensi diabetes melitus tipe 2. Prevalensi prediabetes sangat susah dideteksi pada suatu populasi.

Tujuan: untuk mengetahui prevalensi dan faktor penentu prediabetes pada wanita muda obese (indeks massa tubuh, IMT >25) di Denpasar.

Metode: Penelitian ini termasuk studi cross-sectional dengan variabel penelitian, meliputi aktivitas fisik, pola makan, antropometri pada tingkat obesitas (obesitas ringan IMT 25-30 $\mathrm{kg} / \mathrm{m}^{2}$, obesitas berat IMT $>30 \mathrm{~kg} / \mathrm{m}^{2}$ ) dan jenis obesitas (obesitas perifer lingkar perut $<80 \mathrm{~cm}$, obesitas sentral lingkar perut $>80$ $\mathrm{cm}$ ), serta kadar glukosa darah puasa (normal $<100 \mathrm{mg} / \mathrm{dL}$, prediabetes $-125 \mathrm{mg} / \mathrm{dL}$ ).

Hasil dan Simpulan: prevalensi prediabetes dari subjek adalah

Kata kunci: Prediabetes, Resistensi Insulin, Diabetes Melitus, Faktor Risiko, Obesitas, Obesitas Sentral

Sitasi Artikel ini: Sari, D.A.M.S., Ernawati, S.K., Mahendra, A.N., Weta, I.W. 2020. Prevalensi dan faktor penentu prediabetes pada wanita muda obesitas di Kota Denpasar tahun 2019. Intisari Sains Medis 11 (3): 1000-1004. D0I: 10.15562/ism.v11i3.701
38,1\%. Semua subjek 42 (100\%) memiliki aktivitas fisik harian yang ringan, dengan rata-rata asupan kolesterol yang tinggi ( $>200 \mathrm{mg}$ ) dan asupan PUFA (pure unsaturated fatty-acid) yang rendah $(<10 \%$ dari asupan lemak). Subjek dengan prediabetes mempunyai lingkar perut (lemak visceral) lebih besar dibandingkan dengan subjek dengan kadar gua darah normal $(p=0,023)$. Sebaliknya, tidak didapat hubungan antara lemak subkutan (lipatan kulit bisep dan trisep) dengan kejadian prediabetes $(p>0,05)$. Obesitas sentral bermakna berisiko menderita prediabetes $O R$ 1,76 (1,33$2,33)$ dibandingkan dengan obesitas perifer $(p=0,023)$. Namun, tidak ada risiko yang signifikan $[0 R 2,67 ;(0,738-9,63)(p=0,130)]$ obesitas berat menjadi prediabetes dibandingkan dengan obesitas ringan.

\section{PENDAHULUAN}

Prevalensi prediabetes di Indonesia berdasarkan Toleransi Glukosa Terganggu (TGT) adalah 
Prediabetes merupakan peningkatan glukosa darah antara, di atas glukosa darah normal dan di bawah kadar glukosa darah diabetes mellitus. ${ }^{2}$ Wanita memiliki risiko lebih tinggi mengalami prediabetes dibanding pria. Wanita berisiko lebih tinggi mengalami prediabetes karena wanita lebih sensitif terhadap efek penekanan peningkatan berat badan dibanding pria sehingga risiko overweight dan obesitas lebih tinggi dialami wanita. ${ }^{3}$ Peningkatan prevalensi obesitas bersamaan dengan prevalensi diabetes melitus tipe 2. Kondisi ini adalah asimtomatis (tidak terdapat keluhan maupun gejala, sehingga umumnya kelainan ini tidak terdeteksi). $\mathrm{Hal}$ ini menyebabkan pengendalian prediabetes ini sulit di implementasikan tanpa adanya sistem penapisan (screeming), melalui pemeriksaan glukosa darah secara sistematis dan terstruktur pada masyarakat yang berisiko. Oleh karena itu, prevalensi prediabetes sangat susah dideteksi pada suatu populasi.

Obesitas yang merupakan faktor risiko utama prediabetes, prevalensinya terus mengalami peningkatan di seluruh dunia termasuk Indonesia. Secara umum, faktor risiko prediabetes dibedakan menjadi 2, yaitu faktor risiko yang tidak dapat diubah dan faktor risiko yang dapat diubah. Faktor

Tabel 1. Karakteristik subjek penelitian berdasarkan faktor demografi dan status prediabetes

\begin{tabular}{lccc}
\hline \multirow{2}{*}{ Variabel } & \multicolumn{2}{c}{ Prediabetes } & \multirow{2}{*}{ Total $(\mathbf{n = 4 2 )}$} \\
\cline { 2 - 3 } & Tidak (n=26) & Ya (n=16) & \\
\hline $\begin{array}{l}\text { Umur (th) } \\
\text { (rerata } \pm \mathrm{SB})\end{array}$ & $21,0 \pm 1,78$ & $20,4 \pm 1,15$ & $20,7 \pm 1,05$ \\
Suku $(\mathrm{f}(\%))$ & & & \\
- Bali & $22(52,4)$ & $14(33,3)$ & $36(85,7)$ \\
- Jawa & - & $2(4,76)$ & $2(4,76)$ \\
- Bali & $3(7,14)$ & - & $3(7,14)$ \\
- Cina & $1(2,38)$ & - & $1(2,38)$ \\
\hline Total & $26(61,9)$ & $16(38,1)$ & $42(100)$ \\
\hline
\end{tabular}

Tabel 2. Kadar gula darah puasa (gdp), asupan energi dan nutrien makro menurut status prediabetes

\begin{tabular}{lccc}
\multirow{2}{*}{ Asupan Nutrien } & \multicolumn{2}{c}{ Prediabetes } & \multirow{2}{*}{$\boldsymbol{P}^{*}$} \\
\cline { 2 - 3 } & Tidak (rerata \pm SB) & Ya (rerata \pm SB) & $<0,001$ \\
GDP (mg/dL) & $90,6 \pm 8,29$ & $112 \pm 7,29$ & 0,479 \\
Energi (kkal) & $1735 \pm 612$ & $1608 \pm 597$ & 0,549 \\
Karbohidrat (g) & $188 \pm 69$ & $174 \pm 75$ & 0,934 \\
Protein (g) & $71,7 \pm 38,2$ & $72,8 \pm 43,4$ & 0,639 \\
Lemak (g) & $60,3 \pm 34,7$ & $54,8 \pm 35,1$ & 0,817 \\
PUFA (g) & $14,0 \pm 9,18$ & $13,3 \pm 8,97$ & 0,582 \\
Kolesterol (mg) & $293 \pm 136$ & $267 \pm 147$ &
\end{tabular}

${ }^{\star}$ Dianalisis dengan independent student $t$ test dengan taraf signifikansi $\mathrm{p}<0,05$;

$\mathrm{GDP}=$ gula darah puasa;

PUFA=poly unsaturated fatty acid; $\mathrm{SB}=$ simpangan baku risiko yang tidak dapat diubah meliputi usia dan jenis kelamin. Sedangkan faktor risiko yang dapat diubah adalah gaya hidup, yang meliputi pola makan, aktivitas fisik yang berkontibusi terjadinya obesitas dan obesitas sentral, hipertensi, pendidikan rendah, status sosial ekonomi tinggi, dan juga kebiasaan merokok. ${ }^{1,4}$ Faktor-faktor risiko di atas perlu diidentifikasi karena sangat strategis dalam upaya pencegahan dan penanggulangan prediabetes itu sendiri.

\section{METODE}

Penelitian ini merupakan penelitian deskriptif dengan metode cross-sectional. Responden direkrut dengan cara sosialiasi melalui medsos (media sosial) seperti whatsapp dan line. Pengumpulan data dilakukan sejak Oktober 2019 hingga November 2019. Subjek yang memenuhi kriteria penelitian diundang untuk hadir pada saat pengumpulan data di FK Unud, dalam kondisi puasa 10 jam. Sebelum dilakukan pengumpulan data, subjek penelitian diberikan penjelasan tentang penelitian terlebih dahulu baik mengenai manfaat maupun risiko atau kerugian yang mungkin muncul akibat penelitian ini. Kemudian dilanjutkan dengan menanda tangani persetujuan (inform consent) dan berpartisipasi sebagai subjek penelitian. Kemudian dilakukan pengumpulan data dilakukan pengambilan darah puasa, wawancara untuk mengumpulkan data pola makan dan pengumpulan data antropometri. Nomor Kaji Etik 2298/UN14.2.2.VII.14/LP/2019.

\section{HASIL}

Sebanyak 42 orang subjek yang memnuhi syarat berpartisipasi dalam penelitian ini. Berdasarkan karakteristik demografi, rata-rata umur subjek penelitian 20,7 tahun, dengan kisaran 18-25 tahun. Sebagian besar subjek berasal dari suku Bali 36 orang $(85,7 \%)$, sisanya berasal dari etnis India 3 orang $(7,14 \%)$, Jawa 2 orang $(4,76 \%)$, dan Cina 1 orang $(2,38 \%)$. Dari 42 orang subjek penelitian tersebut didapatkan 16 orang subjek $(38,1 \%)$ sudah menderita prediabetes. Gambaran lebih spesifik karakteristik subjek penelitian berdasarkan status prediabetes dapat dilihat pada Tabel 1 .

Asupan energi dan nutrien makro seperti karbohidrat, protein dan lemak maupun variannya seperti kolesterol dan PUFA, tidak didapat perbedaan antara kelompok yang tidak dengan prediabetes $(p>0,05)$. Rerata asupan energi, karbohidrat, dan protein cukup, akan tetapi asupan lemak tergolong pada level cukup tinggi (lebih dari 50 g) pada kedua kelompok. Akan tetapi asupan kolesterol kedua kelompok tergolong tinggi (lebih dari $250 \mathrm{mg}$ ), sebaliknya asupan asam lemak tidak 
jenuh majemuk -PUFA-nya tergolong rendah (kurang dari dari 30\% dari asupan lemak) terhadap Angka Kecukupan Gizi (AKG) yang dianjurkan untuk orang Indonesia sehat (Tabel 2).

Pada Tabel 3. dapat dilihat terdapat korelasi positif yang sangat kuat antara variabel nilai antropometri untuk menggambarkan massa lemak tubuh sentral (viseral) seperti IMT, berat badan (BB), lingkar perut (Lpe) dan rasio lingkar perut dengan lingkar panggul (RLPePa). Demikian juga antar lemak tubuh subkutan antara lipatan kulit bisep (LKB) dengan lipatan kulit trisep (LKT). Akan

Tabel 3. Matrik korelasi antar berbagai variabel antropometri dan kadar gula darah puasa

\begin{tabular}{llllllll}
\hline & IMT & BB & LPe & RLPePa & LKB & LKT & GDP \\
\hline IMT & 1 & & & & & & \\
BB &, $898^{* *}$ & 1 & & & & & \\
&, 000 & & & & & & \\
LPe &, $805^{* *}$ &, $810^{* *}$ & 1 & & & & \\
&, 000 &, 000 & & & & & \\
RLPePa &, $354^{*}$ &, $355^{*}$ &, $728^{* *}$ & 1 & & & \\
&, 021 &, 021 &, 000 & & & & \\
LKB &, $521^{* *}$ &, $497^{* *}$ &, $427^{* *}$ &, 156 & 1 & & \\
&, 000 &, 001 &, 005 &, 322 & & & \\
LKT &, 268 &, 226 &, 155 &,- 005 &, $601^{* *}$ & 1 & \\
&, 086 &, 151 &, 326 &, 977 &, 000 & & \\
GDP &, 202 &, 268 &, 168 &, 144 &, 005 &,- 216 & 1 \\
&, 200 &, 087 &, 289 &, 363 &, 975 &, 170 & \\
\hline
\end{tabular}

Tabel 4. Perbandingan nilai antropometri antara kelompok prediabetes dengan kelompok tidak prediabetes

\begin{tabular}{lccc}
\hline \multirow{2}{*}{ Variabel Anthropometri } & \multicolumn{2}{c}{ Prediabetes (rerata \pm SB) } & \multirow{2}{*}{$\boldsymbol{P}^{*}$} \\
\cline { 2 - 3 } & Tidak (n=26) & Ya (n=16) & \\
\hline IMT $\left(\mathrm{kg} / \mathrm{m}^{2}\right)$ & $29,3 \pm 4,62$ & $30,9 \pm 3,04$ & 0,238 \\
Berat badan $(\mathrm{kg})$ & $72,4 \pm 12,0$ & $79,8 \pm 10,6$ & $0,049^{\star *}$ \\
Lingkar perut $(\mathrm{cm})$ & $88,9 \pm 11,4$ & $95,7 \pm 6,80$ & $0,037^{\star *}$ \\
Rasio lingkar perut/panggul & $0,820 \pm 0,080$ & $0,872 \pm 0,097$ & 0,067 \\
Lipatan kulit bisep (mm) & $21,2 \pm 7,15$ & $20,2 \pm 7,84$ & 0,691 \\
Lipatan kulit trisep (mm) & $27,9 \pm 8,72$ & $24,7 \pm 8,64$ & 0,255 \\
\hline
\end{tabular}

${ }^{\star}$ Dianalisis dengan independent student $t$ test ${ }^{* *} \mathrm{p}<0,05 ; \mathrm{SB}=\operatorname{simpangan}$ baku; IMT=indeks massa tubuh tetapi, tidak satupun indikator lemak viseral (IMT, $\mathrm{BB}$, Lpe, RLPePa) berkorelasi bermakna dengan indikator lemak subkutan (LKB, LKT). Demikan juga tidak satupun variabel nilai antropometri baik indikator lemak viseral maupun subkutan mempunyai korelasi secara bermakna dengan kadar gula darah puasa.

Pada Tabel 4. dapat dilihat bahwa lingkar perut pada kelompok prediabetes $(95 \mathrm{~cm})$ lebih panjang dibandingkan dengan kelompok yang tidak prediabetes $(88,9 \mathrm{~cm})(\mathrm{p}=0,037)$. Demikian juga berat badan kelompok prediabetes lebih berat secara bermakna bila dibandingkan dengan kelompok tidak prediabetes $(\mathrm{p}=0,049)$. Akan tetapi tidak terdapat perbedaan rasio lingkar perut/lingkar panggul antara kelompok prediabetes dengan kelompok tidak diabetes $(\mathrm{P}=0,067)$. Demikian juga tidak didapat perbedaan IMT $(\mathrm{p}=0,238)$, tebal lipatan kulit trisep $(\mathrm{p}=0,255)$, dan tebal lipatan kulit bisep $(\mathrm{p}=0,691)$ antara indikator kedua kelompok distribusi lemak tubuh tersebut .

Pada Tabel 5. dapat dilihat, besarnya risiko (odd ratio (OR)) terkena prediabetes berdasarkan level dan jenis obesitas. Obesitas sentral secara bermakna berisiko 1,76 (kisaran 1,33-2,33) kali terkena prediabetes dibandingkan dengan obesitas perifer $(\mathrm{p}=023)$. Berdasarkan level obesitas, risiko terkena prediabetes pada obesitas berat 2,67 (kisaran 0,738$9,63)$ kali dibandingkan dengan obesitas ringan, akan tetapi hal ini tidak bermakna secara statistik $(\mathrm{p}=0,130)$.

\section{DISKUSI}

Prevalensi prediabetes pada wanita muda obese pada penelitian ini didapatkan 38\%. Lebih tinggi dari yang dilaporkan oleh Adenkanmbi dkk (2018), dimana prevalensi prediabetes pada perempuan segala umur 20,9\%, demikian juga dibandingkan dengan individu obese untuk kedua jenis kelamin (pria dan wanita) 27,7\%. ${ }^{5} \mathrm{Hal}$ ini dapat dimengerti oleh karena risiko angka kejadian kesakitan prediabetes pada individu obese lebih tinggi daripada individu dengan berat badan normal, demikian juga risiko kejadian prediabetes lebih

Tabel 5. Hubungan risiko level dan jenis obesitas dengan prediabetes

\begin{tabular}{|c|c|c|c|c|c|c|}
\hline & \multirow{2}{*}{ Obesitas } & \multicolumn{2}{|c|}{ Prediabetes (f(\%)) } & \multirow{2}{*}{ Total } & \multirow{2}{*}{$\begin{array}{c}\text { OR } \\
\text { (Cl 95\%) }\end{array}$} & \multirow{2}{*}{$P$} \\
\hline & & Tidak & Ya & & & \\
\hline \multirow{3}{*}{ Level } & Ringan $\left(\mathrm{IMT}<30 \mathrm{~kg} / \mathrm{m}^{2}\right)$ & $16(38,1)$ & $6(14,3)$ & $22(52,4)$ & 2,67 & \\
\hline & Berat $\left(\mathrm{IMT} \geq 30 \mathrm{~kg} / \mathrm{m}^{2}\right)$ & $10(23,8)$ & $10(23,8)$ & $20(47,6)$ & & \\
\hline & Total & $26(61,9)$ & $16(38,1)$ & $42(100)$ & $(0,738-9,63)$ & 0,130 \\
\hline \multirow{3}{*}{ Jenis } & Perifer $(\mathrm{LPe}<80 \mathrm{~cm})$ & $5(11,9)$ & $0(0,0)$ & $5(11,9)$ & 1,76 & \\
\hline & Sentral $(\mathrm{LPe} \geq 80 \mathrm{~cm})$ & $21(50,0)$ & $16(38,1)$ & $37(88,1)$ & & \\
\hline & Total & $26(61,9)$ & $16(38,1)$ & $42(100)$ & $(1,33-2,33)$ & $0,023^{\star}$ \\
\hline
\end{tabular}

OR; Odd Ratio, CI 95\%; Confident Interval 95\%, IMT; indeks massa tubuh, LPe; lingkar perut, Dianalisis dengan $C h i^{2}$ test. ${ }^{*} \mathrm{p}<0,05$. 
tinggi pada perempuan dibandingkan dengan lakilaki. Sedangkan, berdasarkan National Diabetes Statistics Report (2017), juga dilaporkan prevalensi prediabetes pada perempuan $29,3 \%$ lebih rendah daripada laki-laki (36,6\%), sedangkan berdasarkan ras/etnis prevalensi prediabetes orang Asia (35,7\%), ras kulit hitam $(36,3 \%)$, Ispanik $(31,7 \%)$, dan ras kulit putih $(31,5 \%){ }^{6}$

Asupan nutrien yang perlu mendapat perhatian dari komposisi nutrien makro adalah, asupan lemak total relatif tinggi, disertai asupan kolesterol tinggi, sedangkan lemak tidak jenuh (PUFA) relatif rendah. ${ }^{7} \mathrm{Hal}$ ini disebabkan tinggi konsumsi minyak goreng, lemak hewan dan makanan tinggi kolesterol. Hal ini dapat memicu terjadinya resistensi insulin. ${ }^{8}$ Untuk menghambat perkembangan ke arah diabetes melitus penurunan berat badan melalui pengurangan asupan energi harian di bawah 1500 kkal, pengurangan asupan kolesterol (kurang dari 200 g) dan lemak jenuh (kurang dari 50 g), serta peningkatan PUFA omega-3 (1-3 g) ${ }^{6}$

Penderita prediabetes mempunyai berat badan dan lingkar perut lebih tinggi dibandingkan dengan subjek non diabetes. Akan tetapi, bila dilihat korelasi antropometri dengan kadar Gula Darah Puasa (GDP), tidak didapat hubungan bermakna. Hal ini juga dilaporkan oleh penelitian Santi dkk (2018), bahwa korelasi antropometri dengan kadar gula darah puasa, tidak didapat hubungan bermakna. ${ }^{9}$ Manajemen pengendalian berat badan untuk mengurangi massa lemak tubuh khususnya lemak viseral dengan menurunkan lingkar perut. Lemak viseral adalah lemak yang metabolik paling aktif, yang memicu stres oksidatif, proses peradangan dan resistensi insulin. Penurunanan berat badan dan massa lemak tubuh dapat dilakukan dengan imbang energi negatif, dengan pengurangan asupan kalori harian dan peningkatan aktivitas fisik. ${ }^{10,11}$

Identifikasi faktor risiko prediabetes sangat penting dilakukan, dan sangat strategis dalam upaya prevensi kearah berkembangnya bentuk definitif diabetes melitus tipe 2. ${ }^{12}$ Karena pengobatan diabetes melitus tipe 2 hanya bisa mengontrol kadar gula darah, akan tetapi tidak bisa menyembuhkan seperti sebelum terkena diabetes. Berbagai penelitian melaporkan bahwa perilaku (pola makan dan aktivitas fisik), dapat mencegah prediabetes berkembang menjadi diabetes melitus, dan bahkan bisa menjadi normal kembali. Peningkatan aktivitas fisik, pembatasan asupan energi, serta peningkatan asupan asam lemak omega-3 (n-3 PUFA), berpotensi merununkan massa lemak tubuh khusunya lemak viseral. Penurunan lemak viseral secara bermakna dapat menurunkan level inflamasi pada individu obese, ${ }^{13}$ yang pada akhirnya dapat mencegah dan memperbaiki resistensi insulin. ${ }^{14}$

\section{SIMPULAN}

Prevalensi prediabetes pada wanita muda obese pada penelitian ini didapatkan 38\%. Asupan nutrien makro pada semua subjek, seperti asupan lemak total, dan asupan kolesterol relative tinggi di atas AKG, sedangkan asupan lemak tidak jenuh (PUFA), serta asupan serat, relatif rendah di bawah AKG. Akan tetapi tidak didapat perbedaan bermakna asupan nutrient makro antara subjek prediabetes dengan subjek gula darah puasa normal. Penderita prediabetes mempunyai berat badan dan lingkar perut lebih tinggi dibandingkan dengan subjek non prediabetes. Obesitas sentral (lingkar perut $\geq 80 \mathrm{~cm}$ ) berisiko lebih besar terkena prediabetes dibandingkan obesitas perifer (lingkar perut $<80 \mathrm{~cm}$ ). Tidak didapat perbedaan bermakna risiko prediabetes antara obesitas berat (IMT $\geq 30$ $\mathrm{kg} / \mathrm{m}^{2}$ ) dibandingkan dengan obesitas ringan $\left(\left(\mathrm{IMT} \geq 30 \mathrm{~kg} / \mathrm{m}^{2}\right)\right.$.

Identifikasi faktor risiko prediabetes sangat penting dilakukan, dan sangat strategis dalam upaya prevensi kearah berkembangnya bentuk definitif diabetes melitus tipe 2. Obesitas adalah penyakit kronis, sehingga diperlukan intervensi perilaku dalam periode waktu yang panjang untuk mengembalikan pada berat badan normal. Kurang disiplin, kebosanan dan ketidaksabaran dari subjek biasanya menjadi penyebab kegagalan intervensi, sehingga sangat diperlukan upaya Komunikasi, Informasi dan Edukasi (KIE) yang intensif selama periode intervensi pengendalian berat badan.

\section{KONFLIK KEPENTINGAN}

Tidak ada

\section{DAFTAR PUSTAKA}

1. Kementrian Kesehatan RI. 2014. Waspada Diabetes. Pusat Data dan Informasi Kementerian Kesehatan RI. Jakarta

2. DeFronzo, R.A. dan Abdul-Ghani, M. 2011. Assessment and treatment of cardiovascular risk in prediabetes: impaired glucose tolerance and impired fasting glucose. Am J Cardiol 108(Suppl):3B-24B doi:10.1016/j..amjcard.2011.03.013.

3. Williams B. 2004, Epidemiology and pathogenesis of hypertension in people with diabetes mellitus In: Hypertension diabetes. London: Taylor \& Francis Group.

4. Awad, N., Langi, Y., Pandelaki K. 2013. Gambaran Faktor Resiko Pasien Diabetes Melitus Tipe II Di Poliklinik Endokrin Bagian/Smf FK-Unsrat RSU Prof. Dr. R.D Kandou Manado Periode Mei 2011 - Oktober 2011. Jurnal e-Biomedik (eBM) 1:45-49

5. Adekanmbi V.T., Uthman O.T., Erqou S. 2018. Journal of Diabetes. 161-172

6. National Diabetes Statistics Report. 2017. Centers for Disease Control and Prevention. 1-20

7. Wulandari PDA, Wirata G, Putri CWS. Hubungan Antara Asupan Energi, Asupan Protein Dan Aktivitas Fisik Terhadap Status Gizi Penduduk Lanjut Usia Di Wilayah Kerja Upt Kesmas Blahbatuh II, Kecamatan Blahbatuh, Kabupaten Gianyar. E-Jurnal Medika Udayana, 2015; 4(7). 
8. Kalupahana, N.S, Claycombe, K.J., Moustaid-Moussa, N. 2011. (n-3) Fatty acids alleviate adipose tissue, inflammation and insulin resistance: mechanistic insights. Adv Nutr. 2:304-16. doi: 10.3945/an.111.000505.

9. Gray, A., Rebecca, J., Threlkeld, R.J. 2019. Nutritional Recommendations for Individuals with Diabetes. $\underline{w w w}$. Endotex.org

10. Santi B.T., Wiramihardja S., Arisanti N., Raksanagara A.S., Mariani H., Setiawati E.P. 2018. JMJ. 6(2):196-203

11. Dini, M.A.R., Widianti, I.G.A., Wardana, I.N.G. 2018. Prevalensi obesitas dengan menggunakan metode waisthip ratio pada mahasiswa Program Studi Pendidikan Dokter Fakultas Kedokteran Universitas Udayana angkatan 2014. Bali Anatomy Journal 1(1): 9-11

12. Dharmika, I.A.G.W., Negara, M.O., Kurniawan, Y. 2018. Hubungan obesitas sentral dengan testosterone deficiency syndrome (TDS) pada laki-laki dewasa di Denpasar tahun 2017. Bali Anatomy Journal. 1 (2): 35-38
13. Weta IW., Mahadewa T.G.B., Sutirtayasa W.P., Subawa A.A.N., Malik S.G., Widyadharma IP.E. Supplementation with 2:1 ratio of n-6:n-3 polyunsaturated fatty acid improves liver steatosis and serum cytokine levels in young obese balinese women: a randomized clinical trial. Asian J Pharm Clin Res, 2017. DOI: http://dx.doi.org/10.22159/ ajpcr.2017.v10i12.20851

14. Weta, I.W., Sutirtayasa, I.W.P., Subawa, A.A.N., Malik, S.G. 2017. Supplementation 2000mg and 1000mg of linoleic acid and alfa linolenic acid delayed pre diabetic state in Balinese young obese women: A Randomised Clinical Trial. Bali Medical Journal 3(3): S55-S60. DOI:10.15562/ bmj.v3i3.721

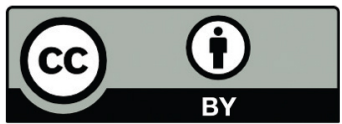

This work is licensed under a Creative Commons Attribution 